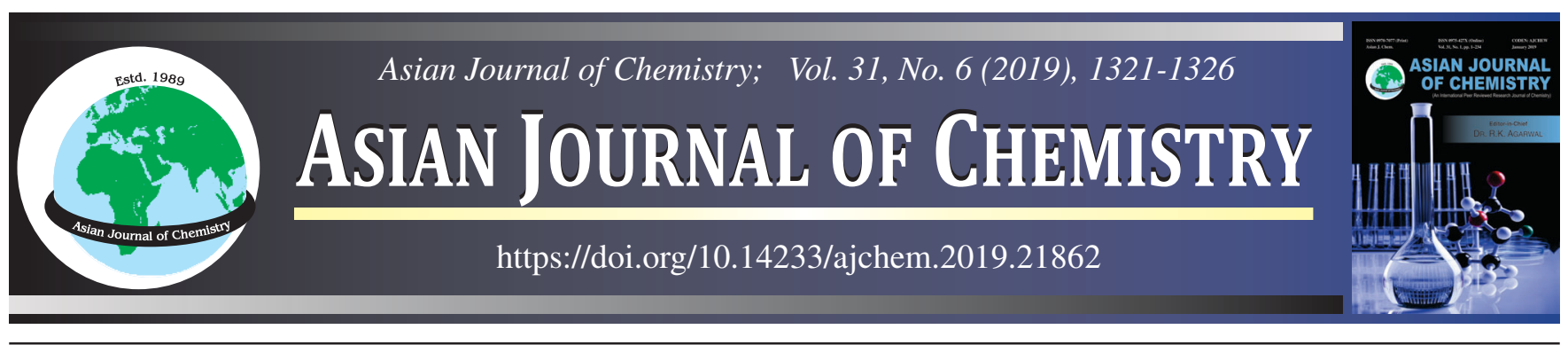

\title{
Effect of Natural Drying Methods on Flavour Profile of Camphor Rich Ocimum americanum L. from North India
}

\author{
M. Bisht, L. Rana, G. Tewari ${ }^{*}$, C. Pande and S. Bhatt
}

Department of Chemistry, D. S. B. Campus, Kumaun University, Nainital-263001, India

*Corresponding author: Fax: +91 5942 235576; Tel: +91 5942 236943; E-mail: geeta_k@ rediffmail.com

Received: 1 December 2018;

Accepted: 22 February 2019;

Published online: 29 April 2019;

AJC-19375

\begin{abstract}
In the present study, fresh aerial parts of Ocimum americanum L. were collected from Ramnagar, India and sun and shade drying was applied until constant weights. The fresh and dried plant materials were hydrodistilled by Clevenger apparatus and the extracted oils were analyzed by GC and GC/MS. One-way ANOVA and correlation were performed to evaluate the difference and correlation between drying treatments using SPSS 16.0. The major compounds of the fresh oil were camphor $(33.41 \%)$, maillol $(11.96 \%)$, $\beta$-selinene $(8.34 \%)$, $\alpha$ | selinene $(6.92 \%), \beta$-gurjunene $(5.43 \%)$ and $(E)$-caryophyllene $(5.07 \%)$. In the dried samples, significant increase $(\mathrm{p}<0.05)$ in the percentage of camphor and maillol was observed while the percentage of $(E)$-cayophyllene, $\beta$-gurjunene, $\beta$-selinene and $\alpha$-selinene significantly $(\mathrm{p}<0.05)$ decreased during drying process. Drying caused loss of fourteen constituents with appearance of four compounds. The oil yield was the highest under sun drying condition.
\end{abstract}

Keywords: Ocimum americanum L., Camphor, Maillol, $\beta$-Selinene, $\alpha$-Selinene, $\beta$-Gurjunene, (E)-Caryophyllene.

\section{INTRODUCTION}

Ocimum americanum L., commonly known as African basil, is a wild aromatic herb with hairy leaves and scented flowers (family Lamiaceae) and is native to tropical Africa [1]. The leaves are used to add flavour in the preparation of soup, tea and salad [2]. The leaf oil of the plant has been traditionally used for the treatment of constipation, diabetes, dysentery, diarrhea and piles $[3,4]$. Furthermore, the essential oil is a potential source of novel compounds such as trans- $\beta$-ocimene, 1,8-cineole, citral, linalool, methyl chavicol, $(E)$-methyl cinnamate, camphor and bisabolenes which are responsible for strong biological activities including antibacterial, antifungal, antioxidant, mosquito repellent, larvicidal and hepatoprotective activities [3-10].

The need for high quality raw material has increased due to the high demand of processed and preserved food products. Drying is one of the common methods of herbs and spices preservation which inhibits enzymatic degradation, reduces moisture content of plants and increases the shelf life of product [11]. Drying also affects the essential oil composition of aromatic and medicinal plants and consequently affects their flavour profile [12]. Although, sun and shade drying are the most econo- mical and widely used methods, they depend on the weather conditions and take longer times [13]. According to Hossain et al. [14] drying may improve the quality of the aroma profile of the plants either due to the formation of new volatile components through oxidation or esterification reactions or the loss of volatile compounds [14]. The effect of different drying methods on the essential oil composition of bisabolene rich $O$. americanum collected from Ranikhet (Inida) was studied by Bhatt et al. [15,16]. Baritaux et al. [17] and Di Cesare et al. [18] have reported the effect of different drying methods on the essential oil composition of Ocimum basilicum. There are several reports on the effect of drying conditions on the essential oil composition of some other Lamiaceae plants such as Plectranthus glandulosus, Mentha piperita, Leonotis leonurus and Mentha spicata [19-23]. Different drying conditions also affect the essential oil yield. The essential oil yield of shade dried Ocimum basilicum, Mentha piperita, Origanum vulgare and Origanum onites was the highest [24-26]. However, according to a study from United States, neither drying duration nor drying condition had a significant effect on oil yield of Mentha spicata [27]. These drying studies have revealed that the essential oil composition of Lamiaceae plants varied with varying temperature and humidity

This is an open access journal, and articles are distributed under the terms of the Creative Commons Attribution-NonCommercial-ShareAlike 4.0 (CC BY-NC-SA 4.0) International License which allows readers to freely read, download, copy, distribute, print, search, or link to the full texts of its articles and to use them for any other lawful non-commercial purpose as long as the original source is duly acknowledged. 
conditions. Selection of optimized drying method could assist in maintaining the quality of the oil and minimizing the loss of volatiles.

After surveying the existing literature, it was found that no work has been reported on the impact of shade and sun drying on the flavour profile of camphor rich Ocimum americanum from India. Therefore, the aim of the present work was to compare the effect of different natural drying methods on the flavour profile of Ocimum americanum collected from Ramnagar, India.

\section{EXPERIMENTAL}

Collection and identification of plant material: Fresh aerial parts of Ocimum americanum L. $(6 \mathrm{~kg})$ at flowering stage were collected from the wild field of Ramnagar (India) in the month of October. A fraction of plant material was sun $\left(25 \pm 5^{\circ} \mathrm{C}\right)$ and shade $\left(20 \pm 5^{\circ} \mathrm{C}\right)$ dried until constant weight was obtained. The identification of the plant was done at Botanical Survey of India (BSI), Dehradun, India (Acc No. 116348).

Isolation of essential oils: Fresh, shade and sun dried plant materials were sliced into small parts and $1000 \mathrm{~g}, 500 \mathrm{~g}$ and $500 \mathrm{~g}$ of each sample was extracted by using hydrodistillation method in a Clevenger apparatus for $5 \mathrm{~h}[28]$ and $1 \mathrm{~mL}, 1 \mathrm{~mL}$ and $1.5 \mathrm{~mL}$ oils were obtained, respectively. The oils were dried over anhydrous sodium sulphate and stored in glass vials. The sealed glass vials were stored in BOD incubator prior to the analysis [28]. All the experiments were conducted in three replicates.

Analysis of essential oils: Shimadzu 2010 GC fitted with Rtx- 5 capillary column $(30 \mathrm{~m} \times 0.25 \mathrm{~mm}$ with film thickness $0.25 \mu \mathrm{m})$ and FID was used for oil analysis. For shade dried oil analysis, the column temperature was programmed at $50{ }^{\circ} \mathrm{C}$ (hold time: $2 \mathrm{~min}$ ) to $210^{\circ} \mathrm{C}$ (hold time: $2 \mathrm{~min}$ ) at $3{ }^{\circ} \mathrm{C} \mathrm{min}{ }^{-1}$ and then $210-280^{\circ} \mathrm{C}$ at $10^{\circ} \mathrm{C} \mathrm{min}^{-1}$ with final hold time of 14 $\min$. For fresh and sun dried oil, the column temperature was programmed at $50^{\circ} \mathrm{C}$ (hold time: $2 \mathrm{~min}$ ) to $210^{\circ} \mathrm{C}$ (hold time: $2 \mathrm{~min}$ ) at $3{ }^{\circ} \mathrm{C} \mathrm{min}^{-1}$ and then $210-280{ }^{\circ} \mathrm{C}$ at $8{ }^{\circ} \mathrm{C} \min ^{-1}$ with final hold time of $14 \mathrm{~min}$. Nitrogen at $30 \mathrm{~mL} / \mathrm{min}$ column head pressure was used as carrier gas. The injector and FID temperature for both the programme was 260 and $270{ }^{\circ} \mathrm{C}$, respectively. The injection volume was $0.1 \mu \mathrm{L}$ neat oil with split mode (split ratio $1: 40)$ [16].

The GC/MS used was 2010 GC coupled with Shimadzu QP 2010 plus with thermal desorption system TD 20 having Rtx -5 capillary column $(30 \mathrm{~m} \times 0.25 \mathrm{~mm}$ with film thickness $0.25 \mu \mathrm{m})$. The GC-MS was programmed in similar conditions to those of GC. Helium was used as carrier gas and the injector temperature was $230^{\circ} \mathrm{C}$. The neat oil $(0.1 \mu \mathrm{L})$ was taken for analysis with split ratio of 1:40. MS were taken at $70 \mathrm{eV}$ with mass range of 40-650 amu [16].

Identification of the components: Identification of the oil components was done on the basis of their retention index (RI) which was calculated with respect to $\mathrm{C}_{9}-\mathrm{C}_{33} n$-alkane series (Polyscience Corp., Niles IL) under same GC conditions, MS Library search (NIST:NIH version 2.1 and WILEY: 7th edition), comparison with the MS literature data [29] and co-injection with standards ( $\alpha$-pinene and limonene). The relative concentration of individual volatile component was calculated on the basis of GC peak area without using any correction factor [16].
Statistical analysis: The mean and standard deviation of triplicate values were calculated using MS-Excel and the analyzed data was presented as mean \pm standard deviation (SD). One-way analysis of variance (ANOVA) was performed to compare mean values of percentage of constituents under different drying methods at a probability level of $\mathrm{p}<0.05$ using SPSS 16.0 statistical software (Duncan Multiple Range Test) [28]. Correlation was also applied using SPSS 16.0 software to correlate the major constituents at probability levels of $\mathrm{p}<0.05$ and $\mathrm{p}<0.01$.

\section{RESULTS AND DISCUSSION}

Essential oil yield: From the GC (Figs. 1-3) and GC/MS data, it was clear that there was variation in the chemical composition of Ocimum americanum after drying. In sun dried sample, the oil yield was maximum. The oil yields of the fresh, shade and sun dried samples were $0.1,0.2$ and $0.3 \%$ (v/w), respectively. In a previous report, essential oil yield of sun dried Ocimum americanum $(0.7 \%)$ was higher as compared to the oil $(0.1 \%)$ of fresh plant [16]. Asekun et al. [21] found that the oils obtained

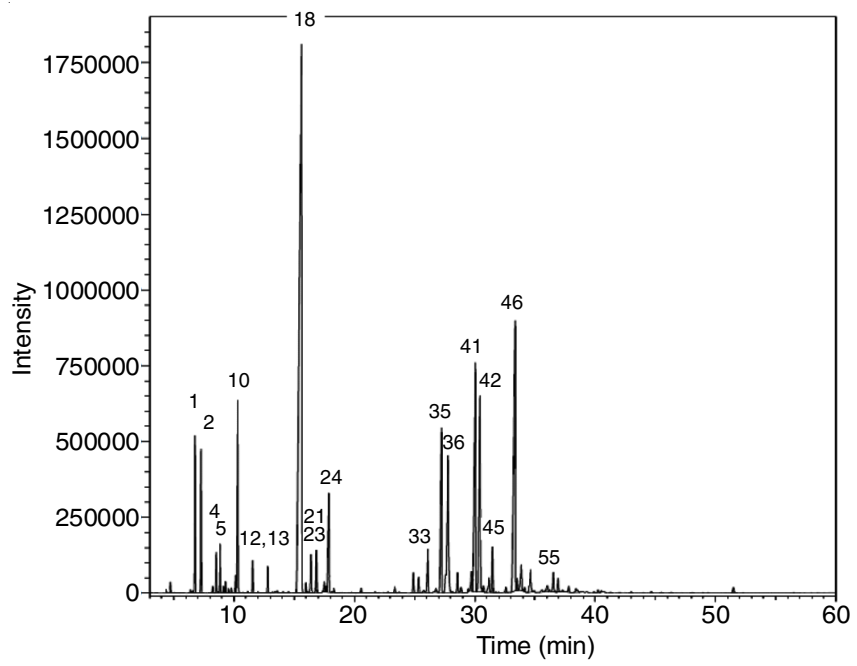

Fig. 1. Gas chromatogram of fresh Ocimum americanum L. oil

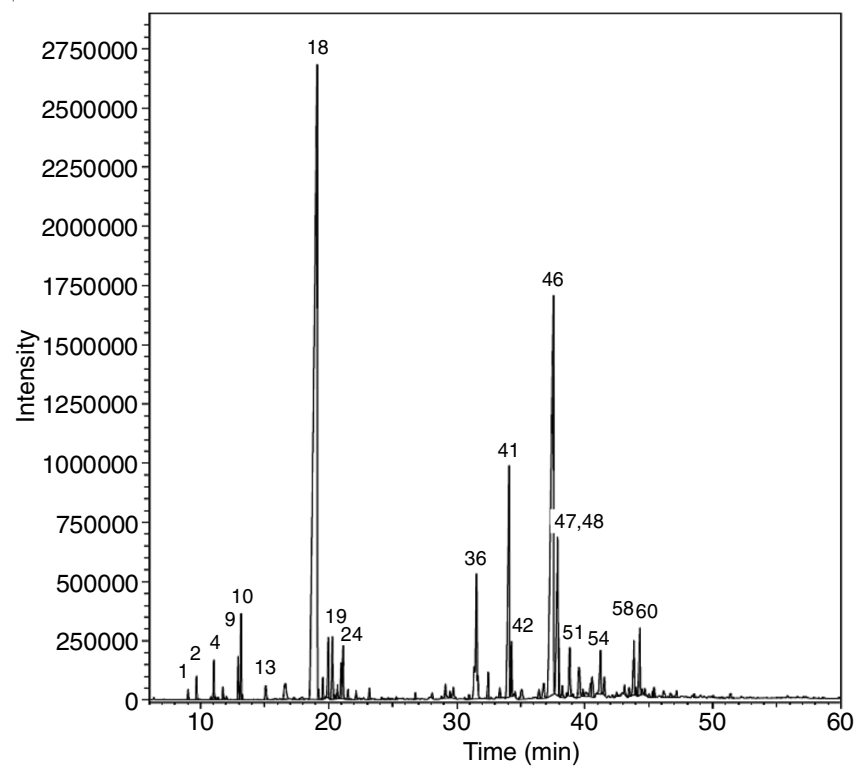

Fig. 2. Gas chromatogram of shade dried Ocimum americanum L. oil 


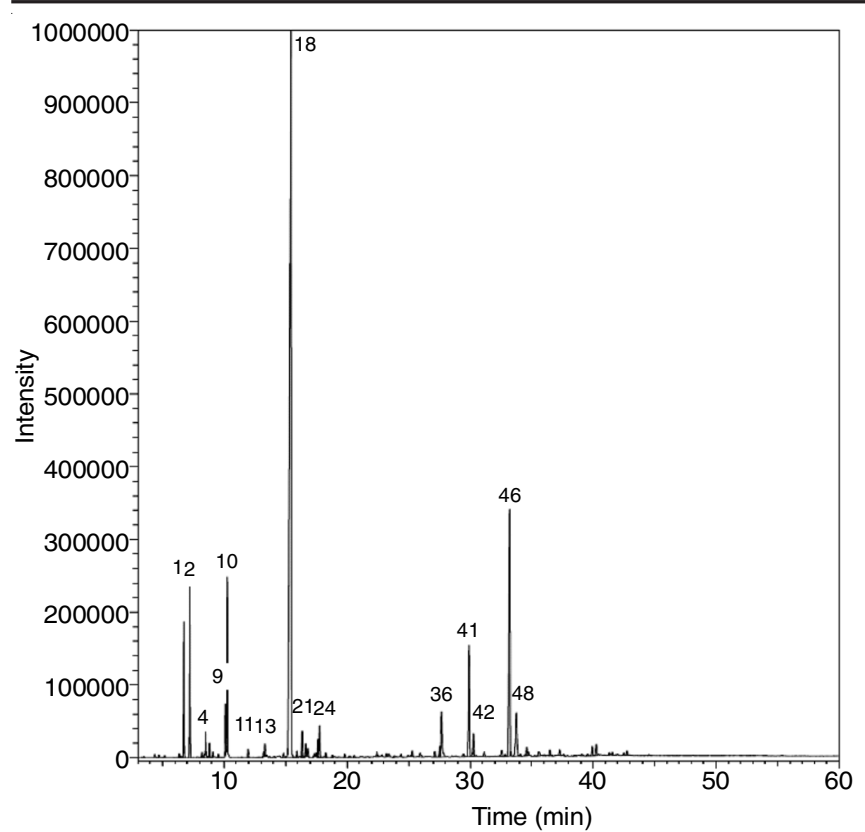

Fig. 3. Gas chromatogram of sun dried Ocimum americanum L. oil

from the aerial parts of sun-dried Leonotis leonurus had better yield as compared to those from the air and oven-dried materials. However, according to Halva [30], the oil yield can be decreased from 2.55 to $1.94 \%$ during drying processes. On the contrary, the highest oil yield was acquired by shade drying treatment in Ocimum basilicum (0.9\%), Mentha piperita (3.68\%), Origanum vulgare $(2.53 \%)$ and Origanum onite $(1.96 \%)$ [24-26].
Essential oil composition: Forty four compounds out of 87 compounds for fresh, 36 out of 80 compounds for shade dried and 35 out of 65 compounds for sun dried $O$. americanum have been identified representing 96.04, 91.93 and $94.09 \%$ of the total oil, respectively (Table-1). Shade drying resulted in loss of $8 \%$ volatile components while sun drying caused the loss of $25 \%$ major volatile constituents of $O$. americanum. The major constituents in the fresh oil were camphor (33.41\%), maaliol (11.96\%), $\beta$-selinene (8.35\%), $\alpha$-selinene $(6.92 \%)$, $\beta$-gurjunene (5.43\%) and (E)-caryophyllene (5.07\%) along with limonene (4.09\%), myrtenol (2.83\%), $\alpha$-pinene $(2.44 \%)$, camphene $(2.33 \%), \beta$-elemene $(1.18 \%)$ and $\delta$-cadinene $(1.11 \%)$ as minor constituents. Trans- $\beta$-ocimene ( $29 \%$ ) and 1,8 -cineole $(41.3 \%)$ were the major components in the essential oil of $O$. americanum from Africa [6] and eugenol (28.46\%) and methyl eugenol (17.34\%) from Egypt [31]. Six chemotypes of Ocimum americanum were observed from India including 1,8-cineole (4.5-16.8\%), methyl chavicol (1.7-12.9\%), eugenol (27.6-38.2 $\%), \beta$-bisabolene (9.9-17.8\%), (E)- $\gamma$-bisabolene $(9.8-15.8 \%)$ rich (Nainital, Banbasa, Rushi and Champawat), methyl chavicol (28.9\%), eugenol (14.7\%), $\beta$-bisabolene (14.7\%), $(E)$ - $\gamma$-bisabolene (7.1\%), aliphatic hydrocarbons $(8.4 \%$ ) rich (Dhoulchina), eugenol (45.2\%), methyl eugenol (14.8\%), (E)-caryophyllene (30.2\%) rich (Rudrapur), linalool (14.2\%), methyl chavicol (78.3\%) rich (Dharchula), 1,8-cineole (11.5-28.4\%), camphor (49.4$42.0 \%)$, eugenol (0-8.6\%) and aliphatic hydrocarbons rich (1.1-11.4\%) (Almora and Kilbury) and camphor (23.0\%), aliphatic hydrocarbons (44.1\%) rich from Mussoorie [9].

TABLE-1

EFFECT OF DRYING ON THE ESSENTIAL OIL COMPOSITION OF O. americanum COLLECTED FROM RAMNAGAR

\begin{tabular}{|c|c|c|c|c|c|c|c|c|c|}
\hline $\begin{array}{l}\text { S. } \\
\text { No. }\end{array}$ & Name of compound & $\mathrm{RI}_{\text {Calculated }}$ & 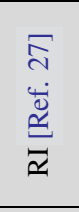 & $\begin{array}{l}\mathrm{RT}_{\text {Fresh }} \\
(\mathrm{min})\end{array}$ & $\begin{array}{c}\text { Percent of } \\
\text { oil (fresh } \\
\text { sample) } \\
\text { (mean } \pm \\
\text { SD) }\end{array}$ & $\begin{array}{c}\mathrm{RT}_{\text {Shade }} \\
\text { dried } \\
(\mathrm{min})\end{array}$ & $\begin{array}{l}\text { Percent of } \\
\text { oil (shade } \\
\text { dried } \\
\text { sample) } \\
\text { (mean } \pm \\
\text { SD) }\end{array}$ & $\begin{array}{c}\mathrm{RT}_{\text {Sun }} \\
\text { dried } \\
(\mathrm{min})\end{array}$ & $\begin{array}{l}\text { Percent of } \\
\text { oil (sun } \\
\text { dried } \\
\text { sample) } \\
\text { (mean } \pm \\
\text { SD) }\end{array}$ \\
\hline 1 & $\alpha$-Pinene & 933 & 932 & 6.8 & $2.44^{\mathrm{a}} \pm 0.51$ & 9.0 & $0.16^{\mathrm{b}}$ & 6.7 & $3.37^{c} \pm 0.35$ \\
\hline 2 & Camphene & 948 & 946 & 7.3 & $2.33^{\mathrm{a}} \pm 0.57$ & 9.7 & $0.37^{\mathrm{b}}$ & 7.2 & $4.39^{c} \pm 0.34$ \\
\hline 3 & $\beta$-Pinene & 976 & 974 & 8.2 & 0.13 & 10.8 & 0.05 & 8.2 & 0.16 \\
\hline 4 & 1-Octen-3-ol & 980 & 974 & 8.5 & 0.73 & 11.0 & 0.62 & 8.5 & 0.79 \\
\hline 5 & Myrcene & 991 & 988 & 8.8 & 0.85 & 11.2 & 0.06 & 8.8 & 0.45 \\
\hline 6 & $\alpha$-Phellandrene & 1004 & 1002 & 9.3 & 0.20 & - & ND & - & ND \\
\hline 7 & (3Z)-Hexenyl acetate & 1008 & 1004 & 9.6 & 0.08 & 11.7 & 0.20 & 9.5 & 0.11 \\
\hline 8 & $\alpha$-Terpinene & 1016 & 1014 & 9.8 & 0.10 & - & ND & - & ND \\
\hline 9 & $p$-Cymene & 1024 & 1020 & 10.1 & 0.35 & 12.9 & 0.64 & 10.1 & 1.40 \\
\hline 10 & Limonene & 1029 & 1024 & 10.3 & $4.09^{\mathrm{a}} \pm 0.14$ & 13.2 & $1.27^{\mathrm{b}} \pm 0.38$ & 10.3 & $4.99^{c} \pm 0.18$ \\
\hline 11 & 1,8-Cineole & 1031 & 1026 & 10.7 & 0.02 & 13.3 & 0.07 & 11.9 & 0.30 \\
\hline 12 & $\gamma$-Terpinene & 1059 & 1054 & 11.6 & 0.62 & - & ND & - & ND \\
\hline 13 & cis-Sabinene hydrate & 1070 & 1065 & - & ND & 15.1 & 0.33 & 13.2 & 0.18 \\
\hline 14 & Terpinolene & 1089 & 1086 & 12.8 & 0.55 & - & ND & - & $\mathrm{ND}$ \\
\hline 15 & trans-Sabinene hydrate & 1105 & 1098 & - & ND & 17.3 & 0.07 & 13.3 & 0.48 \\
\hline 16 & cis-Limonene oxide & 1134 & 1132 & - & ND & - & ND & 14.8 & 0.18 \\
\hline 17 & 3-iso-Thujanol & 1127 & 1134 & - & ND & 17.9 & 0.12 & - & ND \\
\hline 18 & Camphor & 1151 & 1141 & 15.6 & $33.41^{\mathrm{a}} \pm 0.52$ & 19.1 & $40.45^{\mathrm{b}} \pm 0.18$ & 15.4 & $49.74^{c} \pm 0.39$ \\
\hline 19 & Isomenthol & 1188 & 1179 & - & ND & 20.3 & 1.29 & - & ND \\
\hline 20 & Isoborneol & 1158 & 1155 & 16.0 & 0.20 & - & ND & 15.9 & 0.24 \\
\hline 21 & Borneol & 1168 & 1165 & 16.4 & 0.90 & - & ND & 16.3 & 0.98 \\
\hline 22 & Menthol & 1175 & 1167 & - & - & - & ND & 16.6 & 0.45 \\
\hline 23 & Terpinen-4-ol & 1179 & 1174 & 16.8 & 0.99 & - & ND & 16.8 & 0.30 \\
\hline 24 & Myrtenol & 1200 & 1194 & 17.9 & 2.83 & 21.1 & 1.07 & 17.8 & 1.25 \\
\hline 25 & Verbenone & 1211 & 1204 & 18.3 & 0.09 & 21.5 & 0.17 & 18.3 & 0.16 \\
\hline
\end{tabular}




\begin{tabular}{|c|c|c|c|c|c|c|c|c|c|}
\hline 26 & trans-Carveol & 1221 & 1215 & - & ND & - & ND & 18.8 & 0.08 \\
\hline 27 & Carvone & 1244 & 1239 & - & ND & 23.2 & 0.21 & 19.8 & 0.13 \\
\hline 28 & trans-Myrtanol & 1262 & 1258 & 19.8 & 0.02 & - & ND & - & ND \\
\hline 29 & Myrtenyl acetate & 1327 & 1324 & 20.6 & 0.12 & 26.8 & 0.12 & - & ND \\
\hline 30 & Cyclosativene & 1369 & 1369 & 23.4 & 0.15 & - & ND & - & ND \\
\hline 31 & $\alpha$-Copaene & 1379 & 1374 & 24.9 & 0.50 & 29.1 & 0.30 & 24.9 & 0.07 \\
\hline 32 & $\beta$-Bourbornene & 1388 & 1387 & 25.3 & 0.39 & - & ND & 25.3 & 0.25 \\
\hline 33 & $\beta$-Elemene & 1395 & 1389 & 26.1 & 1.18 & 29.7 & 0.29 & 26.0 & 0.27 \\
\hline 34 & $\alpha$-Gurjunene & 1413 & 1409 & 26.8 & 0.12 & - & ND & - & $\mathrm{ND}$ \\
\hline 35 & (E)-Caryophyllene & 1425 & 1417 & 27.2 & $5.07^{\mathrm{a}} \pm 0.59$ & - & ND & 27.1 & $0.25^{\mathrm{b}}$ \\
\hline 36 & $\beta$-Gurjunene & 1438 & 1431 & 27.8 & $5.43^{\mathrm{a}} \pm 0.12$ & 31.6 & $3.84^{\mathrm{b}} \pm 0.21$ & 27.7 & $2.27^{\mathrm{c}} \pm 0.29$ \\
\hline 37 & $\alpha$-Humulene & 1458 & 1452 & 28.6 & 0.50 & - & ND & - & ND \\
\hline 38 & 9-epi-(E)-Caryophyllene & 1464 & 1464 & 28.9 & 0.17 & - & ND & - & ND \\
\hline 39 & $\alpha$-Amorphene & 1482 & 1483 & 29.5 & 0.08 & - & ND & - & ND \\
\hline 40 & Germacrene D & 1486 & 1484 & 29.7 & 0.77 & - & ND & - & ND \\
\hline 41 & $\beta$-Selinene & 1494 & 1489 & 30.1 & $8.34^{\mathrm{a}} \pm 0.29$ & 34.1 & $6.60^{\mathrm{b}} \pm 0.10$ & 30.0 & $4.56^{c} \pm 0.18$ \\
\hline 42 & $\alpha$-Selinene & 1502 & 1498 & 30.4 & $6.92^{\mathrm{a}} \pm 0.30$ & 34.3 & $0.93^{\mathrm{b}}$ & 30.3 & $0.93^{\mathrm{b}}$ \\
\hline 43 & Germacrene A & 1510 & 1508 & 30.7 & 0.14 & - & $\mathrm{ND}$ & - & ND \\
\hline 44 & 7-epi- $\alpha$-Selinene & 1520 & 1520 & 31.2 & 0.47 & 35.1 & 0.38 & 31.2 & 0.22 \\
\hline 45 & $\delta$-Cadinene & 1528 & 1522 & 31.5 & 1.11 & - & ND & - & ND \\
\hline 46 & Maaliol & 1577 & 1566 & 33.4 & $11.96^{\mathrm{a}} \pm 0.44$ & 37.5 & $20.17^{\mathrm{b}} \pm 0.13$ & 33.2 & $11.92^{\mathrm{a}} \pm 0.07$ \\
\hline 47 & Globulol & 1598 & 1590 & 33.5 & 0.25 & 37.9 & 4.38 & - & ND \\
\hline 48 & Viridiflorol & 1600 & 1592 & - & ND & 38.0 & 0.77 & 33.8 & 2.69 \\
\hline 49 & Juneol & 1617 & 1618 & - & ND & 38.8 & 1.05 & - & ND \\
\hline 50 & 1-epi-Cubenol & 1634 & 1627 & 34.1 & 0.09 & - & ND & 34.1 & 0.09 \\
\hline 51 & Muurola-4,10(14)-dien- $\beta$-ol & 1634 & 1630 & - & ND & 39.6 & 0.97 & - & ND \\
\hline 52 & Caryophylla-4(12),8(13)-dien-5 $\alpha$-ol & 1639 & 1639 & - & ND & 40.4 & 0.33 & - & ND \\
\hline 53 & $\alpha$-Muurolol & 1648 & 1644 & 36.0 & 0.27 & 40.6 & 0.51 & 36.0 & 0.08 \\
\hline 54 & Himachalol & 1659 & 1652 & - & ND & 41.2 & 1.11 & - & ND \\
\hline 55 & $\alpha$-Cadinol & 1660 & 1652 & 36.5 & 0.57 & - & ND & 36.5 & 0.30 \\
\hline 56 & Caryophyllene (14-hydroxy-9-epi-E) & 1673 & 1668 & 36.9 & 0.35 & - & ND & - & ND \\
\hline 57 & Eudesma-4(15),7-dien-1 $\beta$-ol & 1698 & 1687 & - & ND & 42.5 & 0.11 & - & ND \\
\hline 58 & Cedroxyde & 1723 & 1713 & - & ND & 43.5 & 0.19 & - & ND \\
\hline 59 & Oplopanone & 1742 & 1739 & - & ND & 43.8 & 1.20 & - & ND \\
\hline 60 & Aristolone & 1767 & 1762 & 38.4 & 0.16 & 44.3 & 1.58 & 38.5 & 0.06 \\
\hline \multicolumn{5}{|c|}{ Total } & 96.04 & & 91.93 & & 94.09 \\
\hline
\end{tabular}

$\mathrm{SD}=$ Standard deviation; $\mathrm{ND}=$ Not detected $(<0.01 \%)$.

Ocimum americanum collected from Ranikhet was dominated by the presence of $\beta$-bisabolene (29.06\%), $(E)$ - $\gamma$-bisabolene (17.49\%), 1,8-cineole (9.14\%), methyl chavicol (7.56 $\%)$ and (Z)- $\beta$-ocimene (7.18\%) [15]. The major components in the shade dried plant were camphor (40.45\%), maaliol $(20.17 \%)$ and $\beta$-selinene $(6.60 \%)$ while in the sun dried plant, the major components were camphor (49.74\%) and maalliol $(11.92 \%)$ (Fig. 4). Fourteen components such as $\alpha$-phellandrene, $\alpha$-terpinene, $\gamma$-terpinene, terpinolene, trans-myrtanol, cyclosativene, $\alpha$-gurjunene, $\alpha$-humulene, 9-epi-(E)-caryophyllene,

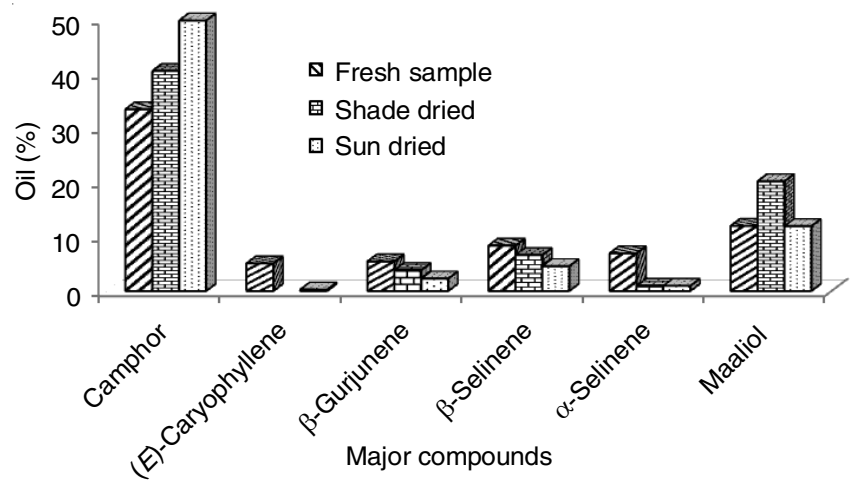

Fig. 4. Variation in the major constituents of $O$. americanum L. after drying $\alpha$-amorphene, germacrene $\mathrm{D}$, germacrene $\mathrm{A}, \delta$-cadinene and caryophyllene (14-hydroxy-9-epi-E) were disappeared during drying while four compounds (cis-sabinene hydrate, transsabinene hydrate, carvone and viridiflorol) appeared in dried plant material which were totally absent in the fresh plant.

Pirbalouti et al. [13], Hamrouni-Sellami et al. [32] and Rahimmalek and Goli [33] have reported the presence of essential oil components in dried samples that were not present in essential oil of fresh samples. Compounds such as 3-iso-thujanol, isomenthol, juneol, muurola-4,10(14)-dien- $\beta$-ol, caryophylla-4(12), 8(13)-dien-5 $\alpha$-ol, eudesma-4(15),7-dien-1 $\beta$-ol, cedroxyde and oplopanone were present only in the shade dried Ocimum americanum. After sun drying, only three components namely cis-limonene oxide, menthol and trans-carveol appeared. Percentage of camphor (33.41-49.74 \%) and maaliol (11.92$20.17 \%)$ increased while that of $(E)$-cayophyllene (5.07-0.25 $\%), \beta$-gurjunene (5.43-2.27\%), $\beta$-selinene (8.34-4.56\%) and $\alpha$-selinene (6.92-0.93\%) decreased on drying $O$. americanum. Content of camphor was also found to increase in O. americanum oil collected from Ranikhet on sun drying [16]. Microwave drying was observed to retain high percentage of marker compounds (eugenol, methyleugenol, eucalyptol and linalool) in Ocimum basilicum as compared to the air and freeze drying 
TABLE-2

CORRELATION AMONG MAJOR CONSTITUENTS OF O. americanum

\begin{tabular}{|c|c|c|c|c|c|c|c|c|c|c|}
\hline Compounds & $\alpha$-Pinene & Camphene & Limonene & Camphor & Endoborneol & Myrtenol & Calarene & $\begin{array}{c}\beta- \\
\text { Selinene }\end{array}$ & $\begin{array}{c}\alpha- \\
\text { Selinene }\end{array}$ & Maillol \\
\hline$\alpha$-Pinene & 1 & 0.968 & $0.999^{*}$ & 0.370 & -0.909 & 0.493 & -0.280 & -0.326 & 0.236 & -0.961 \\
\hline Camphene & & 1 & 0.955 & 0.590 & -0.777 & 0.259 & -0.511 & -0.552 & -0.014 & -0.861 \\
\hline Limonene & & & 1 & 0.324 & -0.929 & 0.534 & -0.233 & -0.280 & 0.283 & -0.973 \\
\hline Camphor & & & & 1 & 0.050 & -0.627 & -0.995 & $-0.999^{*}$ & -0.816 & -0.097 \\
\hline Endoborneol & & & & & 1 & -0.810 & -0.145 & -0.096 & -0.619 & 0.989 \\
\hline Myrtenol & & & & & & 1 & 0.698 & 0.662 & 0.962 & -0.715 \\
\hline Calarene & & & & & & & 1 & $0.999^{*}$ & 0.867 & 0.002 \\
\hline$\beta$-Selinene & & & & & & & & 1 & 0.841 & 0.051 \\
\hline$\alpha$-Selinene & & & & & & & & & 1 & -0.496 \\
\hline Maillol & & & & & & & & & & 1 \\
\hline
\end{tabular}

[18]. It was observed by Baritaux et al. [17] that the contents of methyl chavicol and eugenol decreased along with the significant increase in the content of trans-bergamotene, linalool and 1,8-cineole in basil (Ocimum basilicum L.) [17]. The percentage of oxygenated monoterpenes and oxygenated sesquiterpenes increased in O. americanum. On the other hand, the percentage of sesquiterpene hydrocarbons decreased on shade and sun drying of Ocimum americanum. Increase in the percentage of monoterpene hydrocarbons was noted after sun drying and decrease in the percentage of monoterpene hydrocarbons was observed after shade drying (Fig. 5).

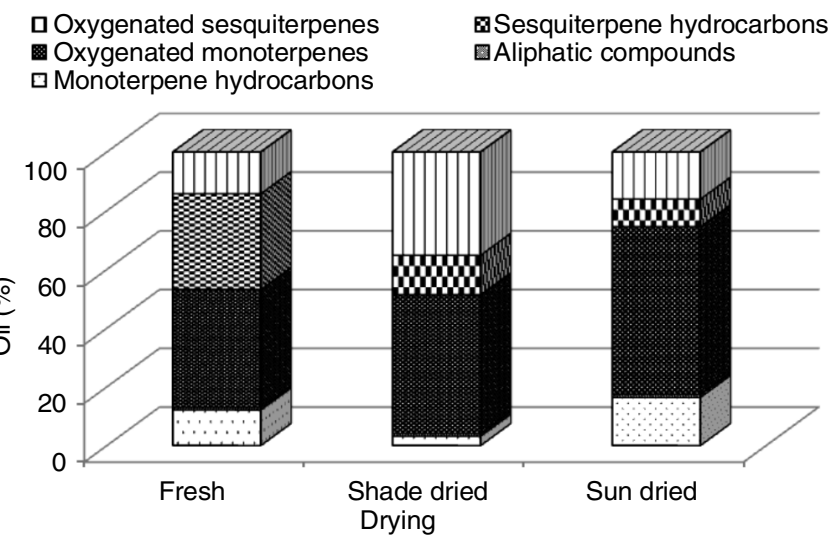

Fig. 5. Comparative class composition of essential oils of $O$. americanum affected by drying

Correlation among major constituents: Correlation analysis of 10 major constituents was done to evaluate relationship between drying methods. $\alpha$-Pinene was significantly and positively correlated with limonene $(r=0.999 ; p<0.05)$ while calarene was positively correlated $(r=0.999 ; p<0.05)$ with $\beta$-selinene. Camphor was found to be negatively correlated ( $\mathrm{r}$ $=-0.999 ; \mathrm{p}<0.05)$ to $\beta$-selinene $($ Table- 2$)$.

\section{Conclusion}

In the present study, the essential oil composition of aerial parts of Ocimum americanum subjected to natural drying methods were compared with fresh oil using One-way ANOVA. Camphor and maaliol were the common major constituents in fresh and dried materials. Oil content and percentage of camphor and maaliol were increased significantly $(\mathrm{p}<0.05)$ in sun dried material. Therefore, sun drying could be used a significant drying method for Ocimum americanum.

\section{ACKNOWLEDGEMENTS}

The authors are grateful to Kumaun University, Nainital, India for financial support and Head, Department of Chemistry, D.S.B. Campus, Kumaun University, Nainital, India for providing the necessary research facilities.

\section{CONFLICT OF INTEREST}

The authors declare that there is no conflict of interests regarding the publication of this article.

\section{REFERENCES}

1. J. Drobnick, The Smell Culture Reader, Berg Publishers: Oxford, New York (2006).

2. I.H.N. Bassole, C.T. Ouattara, S.A. Traore, R. Nebie, A. Savadogo, N. Barro and S.A. Traore, Afr. J. Biotechnol., 4, 1156 (2005).

3. T.C. Kazembe and M. Chaibva, Bull. Environ. Pharm., Life Sci., 1, 64 (2012).

4. B.T. Aluko, O.I. Oloyede and A.J. Afolayan, Pak. J. Biol. Sci., 16, 22 (2013);

https://doi.org/10.3923/pjbs.2013.22.30.

5. R.F. Vieira and J.E. Simon, Econ. Bot., 54, 207 (2000); https://doi.org/10.1007/BF02907824.

6. F. Tchoumbougnang, P.H.A. Zollo, F. Avlessi, G.A. Alitonou, D.K. Sohounhloue, J.M. Ouamba, A. Tsomambet, N. Okemy-Andissa, E. Dagne, H. Agnaniet, J.M. Bessiere and C. Menut, J. Essent. Oil Res., 18, 194 (2006);

https://doi.org/10.1080/10412905.2006.9699064.

7. K. Carovic-Stanko, S. Orlic, O. Politeo, F. Strikic, I. Kolak, M. Milos and Z. Satovic, Food Chem., 119, 196 (2010); https://doi.org/10.1016/j.foodchem.2009.06.010.

8. K. Saeio, W. Chaiyana and S. Okonogi, Drug Discov. Ther, 5, 144 (2011); https://doi.org/10.5582/ddt.2011.v5.3.144.

9. S. Singh, G. Tewari, C. Pande and C. Singh, J. Essent. Oil Res., 25, 278 (2013);

https://doi.org/10.1080/10412905.2013.775079.

10. S. Bhatt, G. Tewari, D. Punetha, J. Diwakar and C. Pande, Indian Perfumer, 60, 23 (2016).

11. H.-W. Xiao, Z. Pan, L.-Z. Deng, H.M. El-Mashad, X.-H. Yang, A.S. Mujumdar, Z.-J. Gao and Q. Zhang, Inform. Process. Agric., 4, 101 (2017); https://doi.org/10.1016/j.inpa.2017.02.001.

12. M. Mahmoodi Sourestani, M. Malekzadeh and A. Tava, J. Essent. Oil Res., 26, 177 (2014); https://doi.org/10.1080/10412905.2014.882274.

13. A. Ghasemi Pirbalouti, E. Mahdad and L. Craker, Food Chem., 141, 2440 (2013);

https://doi.org/10.1016/j.foodchem.2013.05.098.

14. M.B. Hossain, C. Barry-Ryan, A.B. Martin-Diana and N.P. Brunton, Food Chem., 123, 85 (2010); https://doi.org/10.1016/j.foodchem.2010.04.003. 
15. S. Bhatt, G. Kunwar, G. Tewari, A. Rani and M. Bisht, ESSENCE-Int. J. Environ. Rehabil. Conserv., 2, 54 (2015).

16. S. Bhatt, G. Tewari, C. Pande and L. Rana, J. Essent. Oil Bear. Pl., 21, 1385 (2018); https://doi.org/10.1080/0972060X.2018.1543031.

17. O. Baritaux, H. Richard, J. Touche and M. Derbesy, Flavour Frag. J., 7, 267 (1992); https://doi.org/10.1002/ffj. 2730070507.

18. L.F. Di Cesare, E. Forni, D. Viscardi and R.C. Nani, J. Agric. Food Chem., 51, 3575 (2003); https://doi.org/10.1021/jf021080o.

19. T. Katamssadan, N. Nukenine Elias, U. Detlef and A. Cornel, Int. J. Agron. Agric. Res., 5, 80 (2004)

20. J. Rohloff, S. Dragland, R. Mordal and T.-H. Iversen, J. Agric. Food Chem., 53, 4143 (2005); https://doi.org/10.1021/jf047998s.

21. O.T. Asekun, D.S. Grierson and A.J. Afolayan, J. Sci. Res. Develop., 10, 61 (2006).

22. S.M. Kripanand, S. Guruguntla and S. Korra, J. Food Pharm. Sci., 3, 38 (2015).

23. U. Sadowska, A. Zabinski and K. Mudryk, Agric. Eng., 3, 83 (2015).

24. M.B. Hassanpouraghdam, A. Hassani, L. Vojodi and N. Farsad-Akhtar, J. Essent. Oil Bear. Pl., 13, 759 (2010);

https://doi.org/10.1080/0972060X.2010.10643892.
25. H. Ayyobi, G.-A. Peyvast and J.-A. Olfati, Ratar. Povrt., 51, 18 (2014); https://doi.org/10.5937/ratpov51-5077.

26. N. Ozdemir, Y. Ozgen, M. Kiralan, A. Bayrak, N. Arslan and M.F. Ramadan, J. Food Meas. Charact., 12, 820 (2018); https://doi.org/10.1007/s11694-017-9696-x.

27. V.D. Zheljazkov, T. Astatkie and E. Jeliazkova, Hort. Sci., 49, 306 (2014); https://doi.org/10.21273/HORTSCI.49.3.306.

28. A. Rani, M. Bisht, C. Pande, G. Tewari, S. Bhatt and M. Matiyani, J. Essent. Oil Bear. Pl., 20, 552 (2017); https://doi.org/10.1080/0972060X.2017.1317606.

29. R.P. Adams, Identification of Essential Oil Components by Gas Chromatography/Mass Spectrometry, Allured Publ., IL, edn 4 (2007).

30. S. Halva, J. Agric. Sci. Finland, 59, 31 (1987).

31. S.E. Abd El-Aziz, E.A. Omer and A.S. Sabra, Res. J. Agric. Biol. Sci., 3, 740 (2007).

32. I. Hamrouni-Sellami, F.Z. Rahali, I.B. Rebey, S. Bourgou, F. Limam and B. Marzouk, Food Bioprocess Technol., 6, 806 (2013); https://doi.org/10.1007/s11947-012-0877-7.

33. M. Rahimmalek and S.A.H. Goli, Ind. Crops Prod., 42, 613 (2013); https://doi.org/10.1016/j.indcrop.2012.06.012. 